\title{
The Effect of Leadership Style and Financial Incentives on Employee Performance
}

\author{
Muhammad Anang Firmansyah ${ }^{1 *}$, Mochamad Mochklas ${ }^{1}$, Andrianto $^{1}$
}

\author{
${ }^{1}$ Faculty of Economics and Business, University of Muhammadiyah Surabaya, Surabaya, Indonesia \\ *Corresponding author. Email: anang.firmansyah@fe.um-surabaya.ac.id
}

\begin{abstract}
This research was conducted with the aim to test and analyse the influence of leadership style and financial incentives both simultaneously and partially, and to find out the variables that dominantly influence the performance of employee on "MJA" Travel in Surabaya. Data collection techniques with interviews, questionnaires, and observations. The respondents of this study were "MJA" Travel employees in Surabaya. The data obtained were tested first with reliability testing, validity test and factor analysis. Processing and data analysis techniques used in this study are multiple regression analysis techniques, with the use of the SPSS program. The value of the $t$ test is greater than $t$ table, it can be concluded that there is a significant positive effect in part of the variable leadership style and financial incentives on employee performance fluctuations "MJA" travel in Surabaya.

Keywords: leadership style, financial incentive, employee performance
\end{abstract}

\section{INTRODUCTION}

Indonesian tourism is one of the supporting pillars that become the country's economic strength so that many workers are absorbed in the tourism industry. To make Indonesian tourism more famous, we need a professional management system that is supported by competent human resources to compete with tourism in other countries. Susilo [13] states that Indonesian tourism should have been managed by Indonesian tourism by means of planned, appropriate and measurable tourism destination governance. If you cannot manage well, it will be difficult for Indonesian tourism to compete with other countries that have tourist attractions that are not inferior to Indonesia. Although there had been a decline in the number of foreign tourists and were still traumatized by the Bali bomb tragedy and the bird flu virus, Bali still had a place in the hearts of foreign tourists who were visiting Bali, or who would visit Bali. Foreign tourist visits to Bali continue to increase along with the increasing confidence of foreign tourists on security in Bali [17]. The higher number of foreign tourist visits to Bali, the demand for travel services has also increased. Travel agency entrepreneurs are competing to offer attractive prices and services. One of them is "MJA" Travel in Surabaya. Seeing business competition in the field of travel agency, human resources are needed consisting of people who have high skills, skills and enthusiasm. Companies must provide work spirit to their HR so that they can work more optimally, more effectively and efficiently in order to improve performance [10]. Performance shows how much the level of seriousness and responsibility of employees in carrying out the tasks assigned [14]. Therefore, a leader is needed who can give enthusiasm to employees so that they can be directed according to what has been assigned. A leader must be able to realize the morale of his employees [7]. This shows that the success or failure of an organization in achieving its goals, it all depends on the leader. Therefore, we need an approach to employees so that leaders can influence their employees. Another factor that affects employee performance is the provision of financial incentives. This is a very sensitive thing because it has to do with money. Providing financial incentives is directly proportional to work performance. The better the employee's performance, the higher the incentives provided by the company.

The high morale of employees is that they do work quickly and precisely. Conversely, low work morale can be seen from the work that is done slowly and much wrong. State employee morale shows how they are responsible for the work that has been given [14]. Leadership is an activity to give influence to employees and delegate tasks so that all work can run as expected before [1]. State leadership is an activity to influence and make all employees participate and contribute to the company so that it can run as expected [16]. State leadership is a skill to give influence to employees so that they want to do work so they can achieve their goals [11]. Leadership style is the style of a leader who treats himself as a good listener. He wants to listen to what is a problem that exists among employees. When making a policy, the leader will discuss it first before making a joint decision [11]. State through the performance assessment of the members of the organization, plans and strategies can be arranged and the steps that need to be taken with respect to the achievement of the desired goals of the organization can be determined [2].

State companies must provide gifts or bonuses to employees who have good achievements by providing incentives in the form of a sum of money outside their salary [15]. State financial incentives are money given by companies as remuneration because they have made the company profitable [6]. The purpose of providing financial incentives is in addition to being used to help the family economy of the employees themselves, it also aims to make employees more enthusiastic to work [8]. 
The success or failure of a company depends on the leader. Whether the leader can bring the company to a predetermined goal or not. There are various ways that leaders do so that employees have high morale. One of them is by implementing a participatory leadership style. By applying this participatory leadership style, the leader positions, himself as a good listener. He will go down to listen to what his complaints are. Before decision making, leaders discuss it first with employees and receive input from them. Employees will be happy to work because they feel valued because they have been involved in decision making. Another way is to provide financial incentives to employees who have good achievements. By giving a bonus in the form of money, the hope is that employees can improve performance and can be an inspiration for other employees to have the same achievement.

State that employee performance is the result of work the quality and quantity achieved by an employee inside carry out their duties in accordance with the responsibilities given to him/her [9]. Employee performance as an achievement get someone to do the task and argues that performance is the result of work achieved by someone, a group of people in the organization, accordingly with the authority and responsibility of each in the framework Efforts to legally check the objectives of the organization concerned breaking the law and in accordance with morals and ethics [4]. Concludes performance as a result employee work seen from aspects of quality, quantity, work time, and cooperation to find the goals set by the organization [5].

\section{RESEARCH METHODS}

The sampling method used is non-probability sampling with Judgmental sampling techniques with the community who have seen product advertisements. The number of samples used in this study were 96 respondents. This study uses the level of interval measurement because researchers want to identify the effect of Leadership Style, Financial Incentive on the Employee Performance. The scale method used and in accordance with the level of interval measurement is a Likert scale. The Likert scale is attitude measurement technique in marketing research. This scale allows respondents to express agreement or disagreement with statements regarding the object of stimulation. Data processing and analysis techniques used in this study are multiple regression analysis techniques, with the completion of using SPSS program. Multiple regression analysis techniques are used to predict how the statement of dependent variable if two or more independent variables as a predictor factor are manipulated. The independent variable of multiple regression must be more than two [12]. The research hypothesis is below.

$\mathrm{H}_{1}$ : Leadership Style effect on Employee Performance.

$\mathrm{H}_{2}$ : Financial Incentive effect on Employee Performance

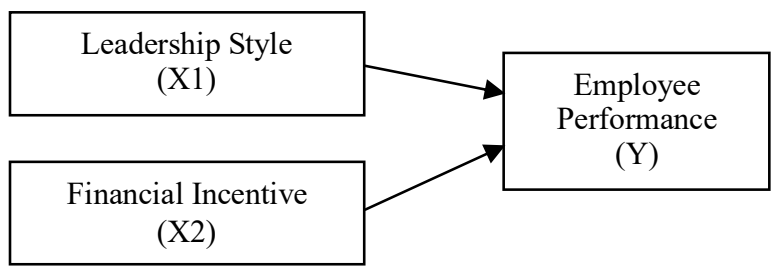

Figure 1 Conceptual Framework

\section{RESULTS AND DISCUSSION}

Table 1 coefficient of matrix correlation

\begin{tabular}{|c|c|c|}
\hline No. & Variables & Determinant \\
\hline 1 & Employee Performance $(\mathrm{Y})$ & 0.050 \\
\hline 2 & Leadership Style $\left(\mathrm{X}_{1}\right)$ & 0.060 \\
\hline 3 & Financial Incentive $\left(\mathrm{X}_{2}\right)$ & 0.088 \\
\hline
\end{tabular}

Table 1 shows that the coefficient of determination of each variable is close to 0 . So, it can be stated that the instrument items of each variable have a strong correlation.

Table 2 PCA value in the leadership style factors

\begin{tabular}{|c|c|c|}
\hline No. & Information & PCA \\
\hline 1. & $\mathrm{X} 1.1$ & 0.795 \\
\hline 2. & $\mathrm{X} 1.2$ & 0.832 \\
\hline 3. & $\mathrm{X} 1.3$ & 0.838 \\
\hline 4. & $\mathrm{X} 1.4$ & 0.843 \\
\hline 5. & $\mathrm{X} 1.5$ & 0.862 \\
\hline
\end{tabular}

Table 2 shows that the PCA value of the participatory leadership style factor fulfills the requirements of more than 0.5 . The total variation of the extraction sums of squared loadings in the participatory leadership style is 69.564 percent more than 60 percent, so participatory leadership style factors can be used in the model.

\section{Table 3 PCA value on financial incentive factors}

\begin{tabular}{|c|c|c|}
\hline No. & Information & PCA \\
\hline 1. & $\mathrm{X} 2.1$ & 0.890 \\
\hline 2. & $\mathrm{X} 2.2$ & 0.768 \\
\hline 3. & $\mathrm{X} 2.3$ & 0.713 \\
\hline 4. & $\mathrm{X} 2.4$ & 0.746 \\
\hline 5. & $\mathrm{X} 2.5$ & 0.875 \\
\hline
\end{tabular}

Table 3 shows that the PCA value of the financial incentive factor has met the requirements of more than 0.5 . The total variation of extraction sums of squared loadings on financial incentives is 64.215 percent over 60 percent, so financial incentive factors can be used in the model.

Table 4 Kaiser Meyer Olkin (KMO) Test Results

\begin{tabular}{|c|c|c|}
\hline No. & Variables & KMO Sig. \\
\hline 1 & Employee Performance $(\mathrm{Y})$ & 0.826 \\
\hline 2 & Leadership Style $\left(\mathrm{X}_{1}\right)$ & 0.844 \\
\hline 3 & Financial Incentive $\left(\mathrm{X}_{2}\right)$ & 0.790 \\
\hline
\end{tabular}


Table 4 shows that the Kaiser Meyer Olkin (KMO) value for each variable is greater than 0.5 with a significance smaller than alpha 5 percent. So, it can be stated that each variable has sufficient sample to carry out factor analysis.

Table 5 Value of measures of sampling adequacy (MSA)

\begin{tabular}{|c|c|c|}
\hline No & Variables & MSA \\
\hline 1 & Employee Performance (Y) & \\
\hline & Y.1 & 0.816 \\
\hline & Y.2 & 0.846 \\
\hline & Y.3 & 0.815 \\
\hline & Y.4 & 0.828 \\
\hline & Y.5 & 0.832 \\
\hline & Y.6 & 0.820 \\
\hline 2 & Leadership Style $\left(\mathrm{X}_{1}\right)$ & \\
\hline & $\mathrm{X} 1.1$ & 0.850 \\
\hline & $\mathrm{X} 1.2$ & 0.879 \\
\hline & $\mathrm{X} 1.3$ & 0.812 \\
\hline & $\mathrm{X} 1.4$ & 0.858 \\
\hline & $\mathrm{X} 1.5$ & 0.825 \\
\hline 3 & Financial Incentive $\left(\mathrm{X}_{2}\right)$ & \\
\hline & $\mathrm{X} 2.1$ & 0.772 \\
\hline & $\mathrm{X} 2.2$ & 0.751 \\
\hline & $\mathrm{X} 2.3$ & 0.790 \\
\hline & $\mathrm{X} 2.4$ & 0.830 \\
\hline & $\mathrm{X} 2.5$ & 0.813 \\
\hline
\end{tabular}

Table 5 shows that the value of the MSA instrument for each variable is greater than 0.5 . So, it can be stated that each model is feasible to be used in the factor test model.

Table 6 Percentage of variance value

\begin{tabular}{|c|c|c|}
\hline No. & Variables & $\begin{array}{c}\text { Percentage of } \\
\text { Variance }\end{array}$ \\
\hline 1 & Employee Performance $(\mathrm{Y})$ & 61.493 \\
\hline 2 & Leadership Style $\left(\mathrm{X}_{1}\right)$ & 69.564 \\
\hline 3 & Financial Incentive $\left(\mathrm{X}_{2}\right)$ & 64.215 \\
\hline
\end{tabular}

Table 6 shows that the Percentage of Variance for each factor is greater than 60 percent. So, it can be stated that the factors of each variable have the ability to explain the variation of the factors.

Table 7 Multiple linear regression test results

\begin{tabular}{|c|c|c|c|c|c|}
\hline \multirow[b]{2}{*}{ Variables } & \multicolumn{2}{|c|}{$\begin{array}{l}\text { Unstandardized } \\
\text { Coefficients }\end{array}$} & \multicolumn{3}{|c|}{$\begin{array}{l}\text { Standardized } \\
\text { Coefficients }\end{array}$} \\
\hline & (B) & $\begin{array}{l}\text { Std. } \\
\text { Error }\end{array}$ & (Beta) & $\mathrm{T}$ & Sig. \\
\hline Leadership Style $\left(\mathrm{X}_{1}\right)$ & 0.412 & 0.111 & 0.412 & 3.713 & 0.001 \\
\hline Financial Incentive $\left(\mathrm{X}_{2}\right)$ & 0.459 & 0.111 & 0.459 & 4.130 & 0.000 \\
\hline Constant & \multicolumn{5}{|c|}{$=\quad-0,00000000127$} \\
\hline $\mathrm{R}$ & \multicolumn{5}{|c|}{0.749} \\
\hline Adjusted R Square & \multicolumn{5}{|c|}{0.541} \\
\hline F count & \multicolumn{5}{|c|}{29.327} \\
\hline Sig. F count & \multicolumn{5}{|c|}{0.000} \\
\hline
\end{tabular}

Based on Table 7, it can be seen that the regression equation produced $\mathrm{Y}=-0.127+0.412 \mathrm{X} 1+0.459 \mathrm{X} 2$.

The interpretation of the equation is as follows. Employee performance will be positive $(-0.127)$ if all independent variables are considered constant at 0 (zero). The participatory leadership style variable coefficient is positive, which means that the better the participatory leadership style, the employee performance on "MJA" Travel in Surabaya is increasing. The financial incentives variable regression coefficient is positive, which means the better financial incentives available to employee of "MJA" Travel in Surabaya is increasing.

\section{CONCLUSION}

Based on the results of the analysis, it can be concluded that participatory leadership style and financial incentives influence both partially and simultaneously on employee performance on "MJA" Travel in Surabaya. Financial incentive variable has a more dominant influence on employee performance on "MJA" Travel in Surabaya with an absolute standardized beta coefficient value of 0.495 . Implication for company that Management Compensation is an award or reward given by the company either directly or indirectly directly to employee. The results of this study indicate that Financial incentives affect performance Employee.

This has implications for the future company is more careful in calculating the magnitude of accuracy employee salaries, this is done to reduce actions or unethical behavior that can occur in a company.

Suggestion based on the results of the analysis, the authors can suggest that leaders in "MJA" Travel in Surabaya more often involve employees in corporate policy making. This research has been attempted and implemented in accordance with scientific procedure, however, still has limitations: 1) Factors that influence Employee Performance in this study only consisted of two variables, Leadership Style and Financial Incentive, while still being many other factors that affect Employee Performance Fluctuations, and 2) There is limited research using a questionnaire, sometimes the answers given by the respondents do not show real situation.

\section{ACKNOWLEDGMENT}

This research was supported by Muhammadiyah University of Surabaya Indonesia. We thank our colleagues from all lecturers of Economics and Business Faculty of Muhammadiyah University of Surabaya Indonesia who provided insight and expertise that greatly assisted the research.

\section{REFERENCES}

[1] Ardana, K (2011) Manajemen Sumber Daya Manusia. Denpasar : Graha Ilmu 
[16] Yukl, G. (2010). Kepemimpinan dalam organisasi. Edisi kelima. Jakarta : PT. Indeks
[2] Firmansah Mohammad, A., Christiananta, B., \& Ellitan, L. (2014). The Effect of Organizational Citizenship Behavior (OCB), Total Quality Management (TQM), Technology Leadership and Service Quality on the Performance of Private Universities in Surabaya. Academic Research International, 5(2), 174-185.

[3] Firmansyah, M. A., \& Fatihudin, D. (2017). Globalisasi Pemasaran (Marketing Globalization). Deepublish.

[4] Firmansyah, M. A., \& Mahardhika, B. W. (2018). Pengaruh Faktor-Faktor Lingkungan Kerja Internal Dan Pekerjaan Terhadap Motivasi Kerja Karyawan Pada PT. Warnatama Cemerlang Gresik. Balance, 15(02).

[5] Firmansyah, M. A., \& Mochklas, M. Saudi Journal of Business and Management Studies (SJBMS) ISSN 2415-6663 (Print).

[6] Hasibuan, Malayu S.P. (2007). Manajemen Sumber Daya Manusia. Edisi Revisi. Jakarta : Bumi Aksara

[7] Kamanjaya, M. (2008). Peluang Pariwisata Bali Di Tengah Persaingan. Global. Bali

[8] Maryanto. (2008). Pengaruh Kepemimpinan dan Motivasi Terhadap Semangat Kerja Anggota Badan Perwakilan Desa (BPD) di Kecamatan Ngadirojo Kabupaten Wonogori. Jurnal Manajemen SDM. 23 (54), $12-15$.

[9] Mangkunegara, P. A, (2010), Manajemen Sumber Daya Manusia Perusahaan, Remaja Rosdakarya Offset, Bandung

[10] Nawawi, H. H. (2009) Manajemen sumber daya manusia untuk bisnis yang kompetitif. Cetakan Kedua. Yogyakarta : Universitas Gajah Mada

[11] Robbins, S P. (2007). Perilaku Organisasi. Alihbahasa Hadyana Pujaatmaka dan Menyamin Molan. Jakarta. PT. Prenhallindo.

[12] Sugiyono (2008). Metode Penelitian Kuantitatif, Kualitatif dan R\&D.,Bandung CV.Alfabeta.

[13] Susilo, A. (2010). Perkembangan Industri Pariwisata Indonesia. Jakarta

[14] Siagian, S P. (2007). Manajemen Sumber Daya Manusia. Edisi revisi. Jakarta: Bumi Aksara

[15] Thoha, M. (2007). Perilaku Organisasi Konsep Dasar dan Aplikasinya. Rajawali. Edisi Pertama.

Cetakan Kelima. Jakarta. 